\title{
https://sordariomycetes.org/, a platform for the identification, ranking and classification of taxa within Sordariomycetes
}

\author{
Bundhun $\mathrm{D}^{1,2}$, Maharachchikumbura $\mathrm{SSN}^{3}$, Jeewon $\mathbf{R}^{4}$, Senanayake $\mathrm{IC}^{5}$, \\ Jayawardena $\mathbf{R S}^{1}$, Hongsanan $\mathrm{S}^{5}$, Samarakoon $\mathrm{MC}^{1,6}$, Dayarathne $\mathrm{MC}^{1}$, \\ Huang SK ${ }^{1,7}$, Perera $\mathbf{R H}^{1,7}$, Jing $\mathrm{Y}^{1,7}$ and Hyde $\mathrm{KD}^{1,8 *}$ \\ ${ }^{I}$ Center of Excellence in Fungal Research, Mae Fah Luang University, Chiang Rai 57100, Thailand \\ ${ }^{2}$ Department of Entomology and Plant Pathology, Faculty of Agriculture, Chiang Mai University, Chiang Mai 50200, \\ Thailand \\ ${ }^{3}$ School of Life Science and Technology, University of Electronic Science and Technology of China, Chengdu 611731, \\ People's Republic of China \\ ${ }^{4}$ Department of Health Sciences, Faculty of Science, University of Mauritius, Reduit, Mauritius \\ ${ }^{5}$ College of Life Science and Oceanography, Shenzhen University, 1068, Nanhai Avenue, Nanshan, Shenzhen 518055, \\ People's Republic of China \\ ${ }^{6}$ Department of Biology, Faculty of Science, Chiang Mai University, Chiang Mai 50200, Thailand \\ ${ }^{7}$ School of Science, Mae Fah Luang University, Chiang Rai 57100, Thailand \\ ${ }^{8}$ Key Laboratory for Plant Diversity and Biogeography of East Asia, Kunming Institute of Botany, Chinese Academy of \\ Sciences, Kunming 650201, Yunnan, People's Republic of China
}

Bundhun D, Maharachchikumbura SSN, Jeewon R, Senanayake IC, Jayawardena RS, Hongsanan S, Samarakoon MC, Dayarathne MC, Huang SK, Perera RH, Jing Y, Hyde KD 2020 https://sordariomycetes.org/, a platform for the identification, ranking and classification of taxa within Sordariomycetes. Asian Journal of Mycology 3(1), 13-21, Doi 10.5943/ajom/3/1/2

\begin{abstract}
The class Sordariomycetes has, over the years, been subjected to numerous taxonomic and phylogenetic changes, resulting in rapid updates in classification. This has resulted in a vast amount of taxonomic information available as publications and in databases. With the aim of compiling all these scattered data and presenting them comprehensively in a single platform, a new website (Sordariomycetes.org), accessible at https://sordariomycetes.org/ is established. This database conveys coherent and up-to-date information on the ranking and classification of taxa within Sordariomycetes. Notes, descriptions and photographic plates of the type or reference materials, phylogenetic trees, the current number of morphologically accepted species and those with molecular data along with their ecological and / or economic importance in each genus are provided. This is a user-friendly platform, which provides easy access to relevant information.
\end{abstract}

Key words - genera - nomenclature - phylogeny - taxonomy - webpage

\section{Introduction}

Being the second largest class in the phylum Ascomycota after the Dothideomycetes (Kirk et al. 2008, Hyde et al. 2013, 2020, Maharachchikumbura et al. 2015, 2016, Jayasiri et al. 2019), the class Sordariomycetes was introduced by Eriksson \& Winka (1997) and is estimated to have diverged around 341 million years ago (Hongsanan et al. 2017). The class was established based on specific morphological characters, such as perithecial ascomata, periphysate ostioles, a paraphysate hamathecium and inoperculate unitunicate or prototunicate asci and molecular data (Alexopoulos et 
al. 1996, Eriksson \& Winka 1997). Sordariomycetes species occupy both terrestrial and aquatic ecosystems with hosts varying from plants to mammals and arthropods to other fungi (Cai et al. 2006, Zhang et al. 2006, Jaklitsch \& Voglmayr 2012, Hyde et al. 2014, Konta et al. 2016, Luo et al. 2019). They are pathogenic, endophytic, saprobic, epiphytic, coprophilous, fungicolous, lichenized or lichenicolous (Maharachchikumbura et al. 2015, 2016, Jeewon et al. 2017, 2018, Rashmi et al. 2019, Hyde et al. 2020). Sordariomycetes also comprises species which act as important biocontrol agents (Kaewchai et al. 2009) and many taxa produce a variety of secondary metabolites that can be potentially exploited for various medicinal and industrial uses (Semenova et al. 2012, Debbab et al. 2013, Xu et al. 2014, Hyde et al. 2019).

Upon the establishment of the class Sordariomycetes, three subclasses, Hypocreomycetidae, Sordariomycetidae and Xylariomycetidae were introduced by Eriksson \& Winka (1997). Since then several studies on Sordariomycetes have been conducted, emphasizing not only on the morphophylogeny, but equally on fossil calibration data and divergence time estimations (Beimforde et al. 2014, Hongsanan et al. 2016, 2017, Pérez-Ortega et al. 2016, Samarakoon et al. 2016, Zhao et al. 2016, Hyde et al. 2017). As a result, the taxonomy has been revised with significant outcomes, including the addition of three subclasses, namely, Diaporthomycetidae, Lulworthiomycetidae and Meliolomycetidae (Maharachchikumbura et al. 2015). Meliolomycetidae was later reduced to the order Meliolales (Hongsanan et al. 2017). The class Sordariomycetes presently comprises seven subclasses Diaporthomycetidae, Hypocreomycetidae, Lulworthiomycetidae, Savoryellomycetidae, Sordariomycetidae, Xylariomycetidae and the recently introduced subclass Pisorisporiomycetidae (Hyde et al. 2020). Within these subclasses, many new taxa have been introduced, several have also been synonymized or assigned to a new rank (Pinnoi et al. 2010, Dayarathne et al. 2017, Hongsanan et al. 2017, Hyde et al. 2017, 2020, Li et al. 2017, Senanayake et al. 2017, Senwanna et al. 2017, Doilom et al. 2018, Huang et al. 2018a, b, Shang et al. 2018, Yang et al. 2018, Lin et al. 2019).

\section{The need for a Sordariomycetes database}

The taxonomy of Sordariomycetes has been subjected to major revisions and this class has been reported to have a higher speciation process (Wang et al. 2010). It is the ambition of mycologists working on this class to solve the taxonomic challenges and present an updated classification given recent changes. This has been supported by the introduction and revision of different taxa within the class (Senanayake et al. 2015, 2018, Daranagama et al. 2018, Réblová \& Štěpánek 2018, Dayarathne et al. 2019, Wang et al. 2019). The primary concept of a database dedicated to Sordariomycetes is to gather all these scattered data and provide a platform through which to communicate them comprehensively. Several other websites have been established to better deal with taxonomic changes, such as Faces of fungi: https://facesoffungi.org/ (Jayasiri et al. 2015), Marine fungi: https://marinefungi.org/ (Jones et al. 2019), One Stop Shop: https://onestopshopfungi.org/ (Jayawardena et al. 2019), Genera of Fungi: https://fungalgenera.org/ (Monkai et al. 2019) and Dothideomycetes website: https://dothideomycetes.org/ (Pem et al. 2019). The present website, https://sordariomycetes.org/ categorically focuses on the class Sordariomycetes and its objectives are to 1) present an up-to-date outline of the class Sordariomycetes, 2) provide notes on the orders, families and genera of Sordariomycetes, and 3) give updated accounts of each genus keeping up with the current literature. The webpage equally imparts a list of references dealing with Sordariomycetes.

\section{The Sordariomycetes webpage}

This webpage provides data on recent taxonomic aspects of Sordariomycetes which will enable mycologists to gain an understanding of the current status of the class. Information on the placement and status of each genus is provided and the website is updated periodically. Each entry is accompanied by notes, descriptions, photographic plates, phylogenetic trees, list of currently accepted species in the genus, ecological and/or economic significance and additional relevant 
information acquired through other web links, namely, Faces of fungi, Marine Fungi, One Stop Shop and Genera of Fungi.

\section{Construction}

The database is assigned only to fungi belonging to the class Sordariomycetes. Relevant taxa listed in the most recent classification (Hyde et al. 2020) are retrieved and reviewed. For each entry, either the Index Fungorum, FacesofFungi, MycoBank and/ or herbaria numbers are provided. GenBank numbers for sequence data if available for the species studied to represent each genus are also provided. The database is continually updated as new information pertaining to the class becomes available. Curators with mycological expertise have been invited to share their knowledge, monitor the webpage and suggest improvements with the aim of ensuring an update of the classification of Sordariomycetes (Table 1). Other interested parties are encouraged to contact the moderator and offer suggestions or their service as curators.

Table 1 List of curators for Sordariomycetes website.

\begin{tabular}{|c|c|c|c|}
\hline Position & Name & Fungal Group & Contact detail \\
\hline Head & Sajeewa & Sordariomycetes & sajeewa83@yahoo.com \\
\hline Curator & Maharachchikumbura & & \\
\hline Managing & Digvijayini Bundhun & Sordariomycetes & digvi221993@gmail.com \\
\hline Curator & & & \\
\hline \multirow[t]{12}{*}{ Curators } & Indunil Senanayake & Diaporthomycetidae & indunilchinthani@gmail.com \\
\hline & Ruvishika & Phytopathogenic & ruvi.jaya@yahoo.com \\
\hline & Jayawardena & Sordariomycetes & \\
\hline & Sinang Hongsanan & Meliolales & sinang333@gmail.com \\
\hline & Monika Dayarathne & Marine Sordariomycetes & monidaya40@gmail.com \\
\hline & Shi-Ke Huang & Sordariomycetidae & cocohuangsk@gmail.com \\
\hline & Rekhani Perera & Hypocreomycetidae & hansi.rekha2@gmail.com \\
\hline & Milan Samarakoon & Xylariomycetidae & samare.ag.rjt@gmail.com \\
\hline & Jing Yang & Freshwater & yangjing5633@gmail.com \\
\hline & & Sordariomycetes & \\
\hline & Rajesh Jeewon & Sordariomycetes & r.jeewon@uom.ac.mu \\
\hline & Kevin Hyde & Sordariomycetes & kdhyde3@gmail.com \\
\hline
\end{tabular}

\section{Database interface and visualization}

The website, https://sordariomycetes.org/, is user-friendly, allowing easy access to the quest of interest. The webpage includes the following main headings:

- Home: The homepage briefly introduces the Sordariomycetes database by listing the aims for establishing the website and providing 'highlights of information' related to the class (Fig. 1).

- Outline: The 'Outline' gives an overall taxonomic classification of the orders, families and genera of Sordariomycetes under each subclass.

- Archives: This section catalogues the different orders of Sordariomycetes in a systematic way; a click on an order will first reveal the families and clicking on each family will unfold the genera accommodated therein (Fig. 5).

- Curators: The 'Curators' section provides a list and contact details of the curators of the webpage.

- History: This segment provides a brief account of the classification of Sordariomycetes.

- References: A list of the citations used in the entries, history and other information related to the class is provided under this heading.

- News: This segment communicates important events and noteworthy information related to Mycology. 
- Contact: This section gives the contact details of the website and equally offers interested users the opportunity to provide their comments and suggestions.

In addition, the right-hand side of the homepage includes a search box where information on a specific genus can be searched by entering the name of the genus (Fig. 2). Beneath the search box, the recently uploaded news and genera are briefly listed under 'Recent News' and 'Recent Genus' titles. The list of genera available under this 'Recent Genus' section allows quick access for the user to browse, explore and switch between genera (Fig. 3). Clicking on the genus name will unfold information on the genus, type species, herbarium or reference material studied, classification, phylogeny, and ecological and/or economic significance (Fig. 4).

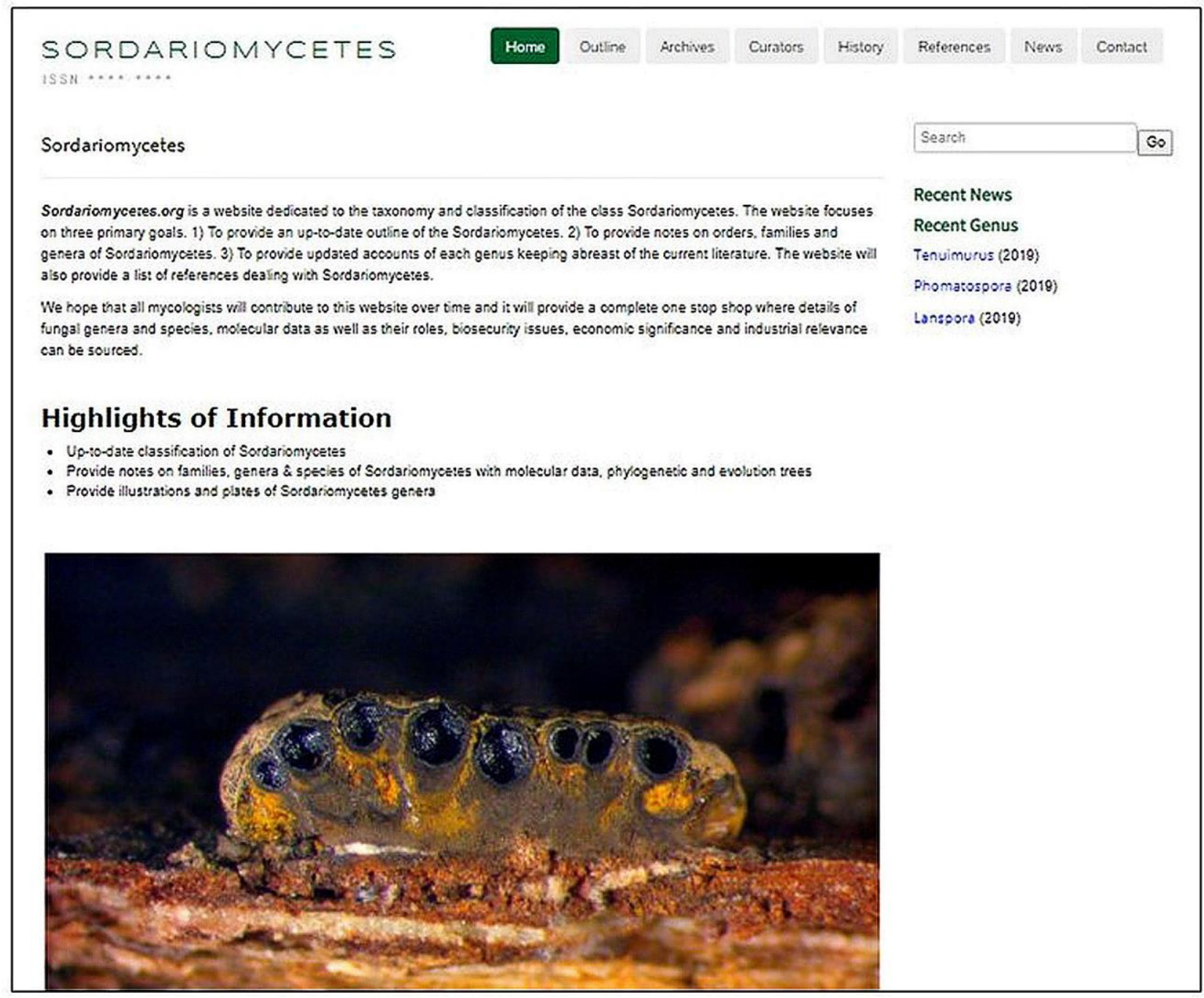

Fig. 1 - View of the Sordariomycetes web homepage. 


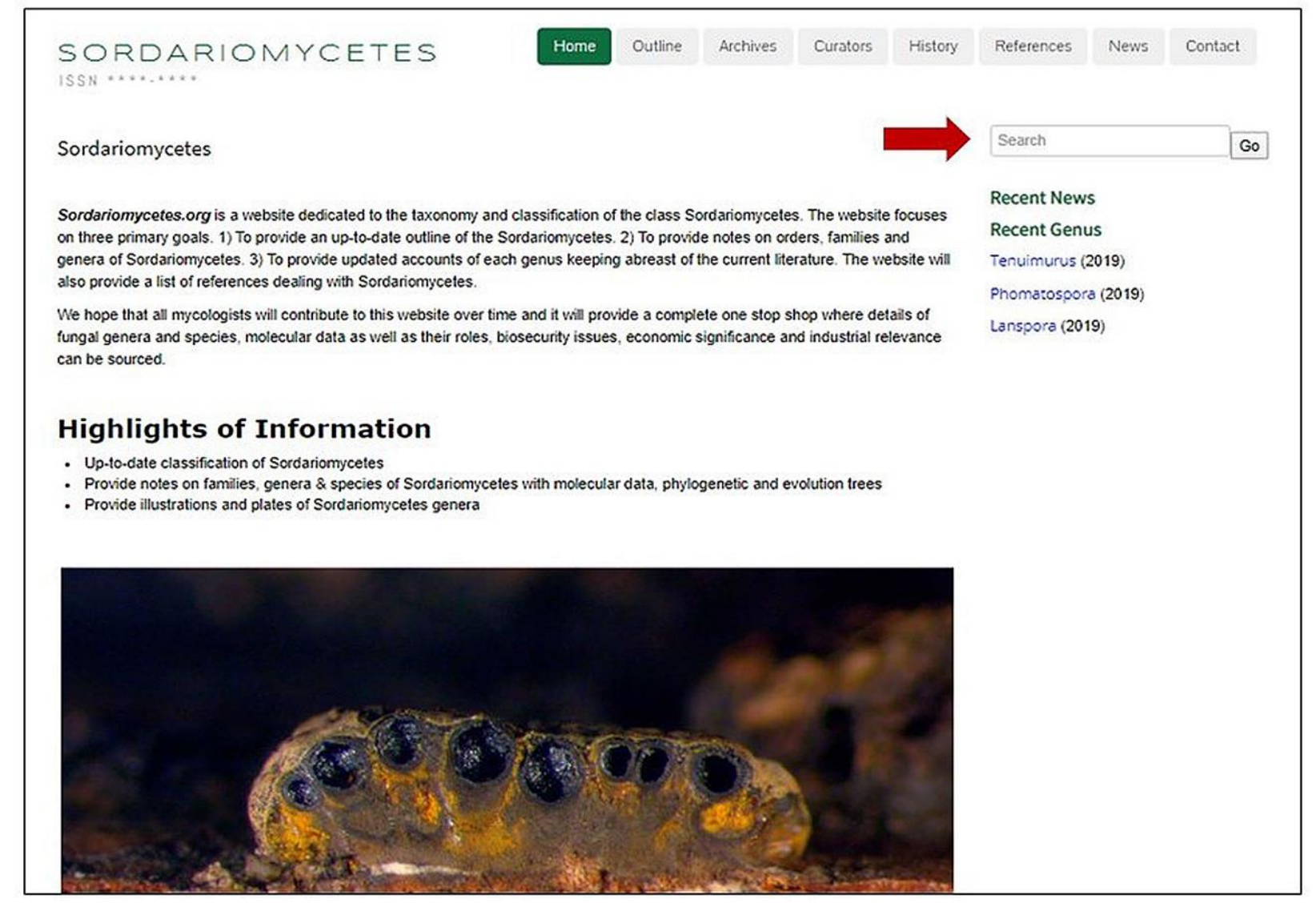

Fig. 2 - Red arrow indicates Search box to enter the taxon name.

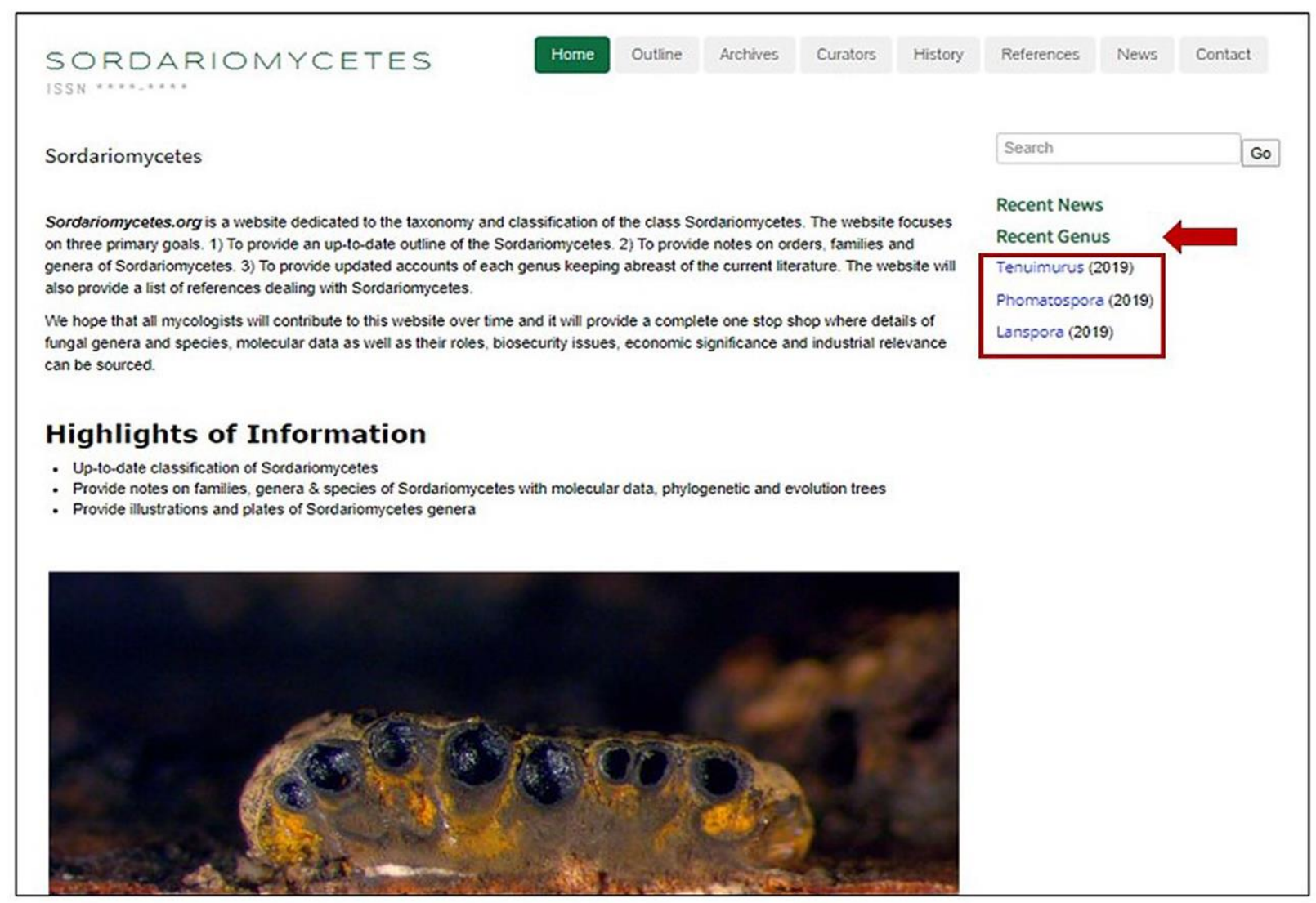

Fig. 3 - List of genera under 'Recent Genus' to enable easy access. 


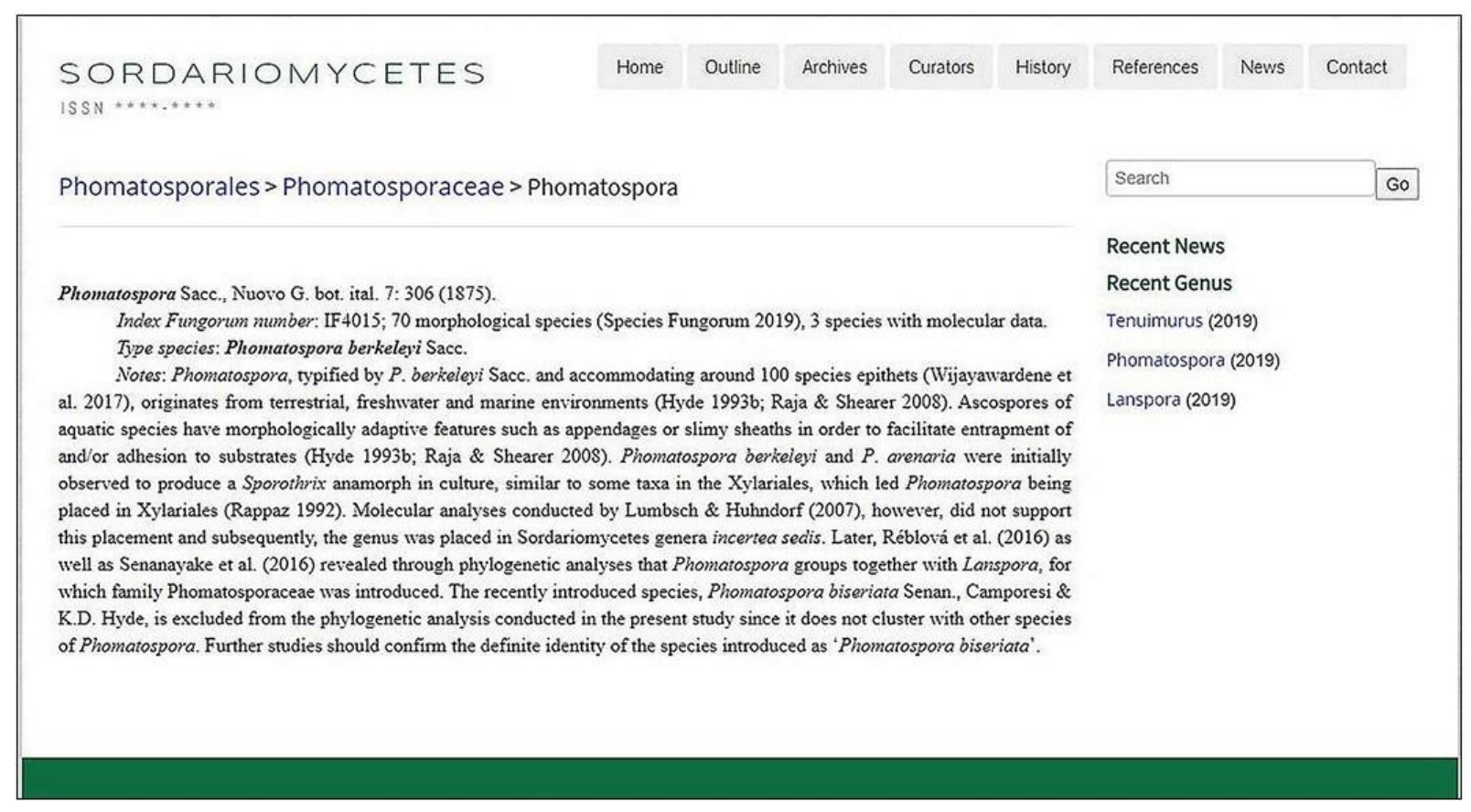

Fig. 4 - Sordariomycetes genus entry.

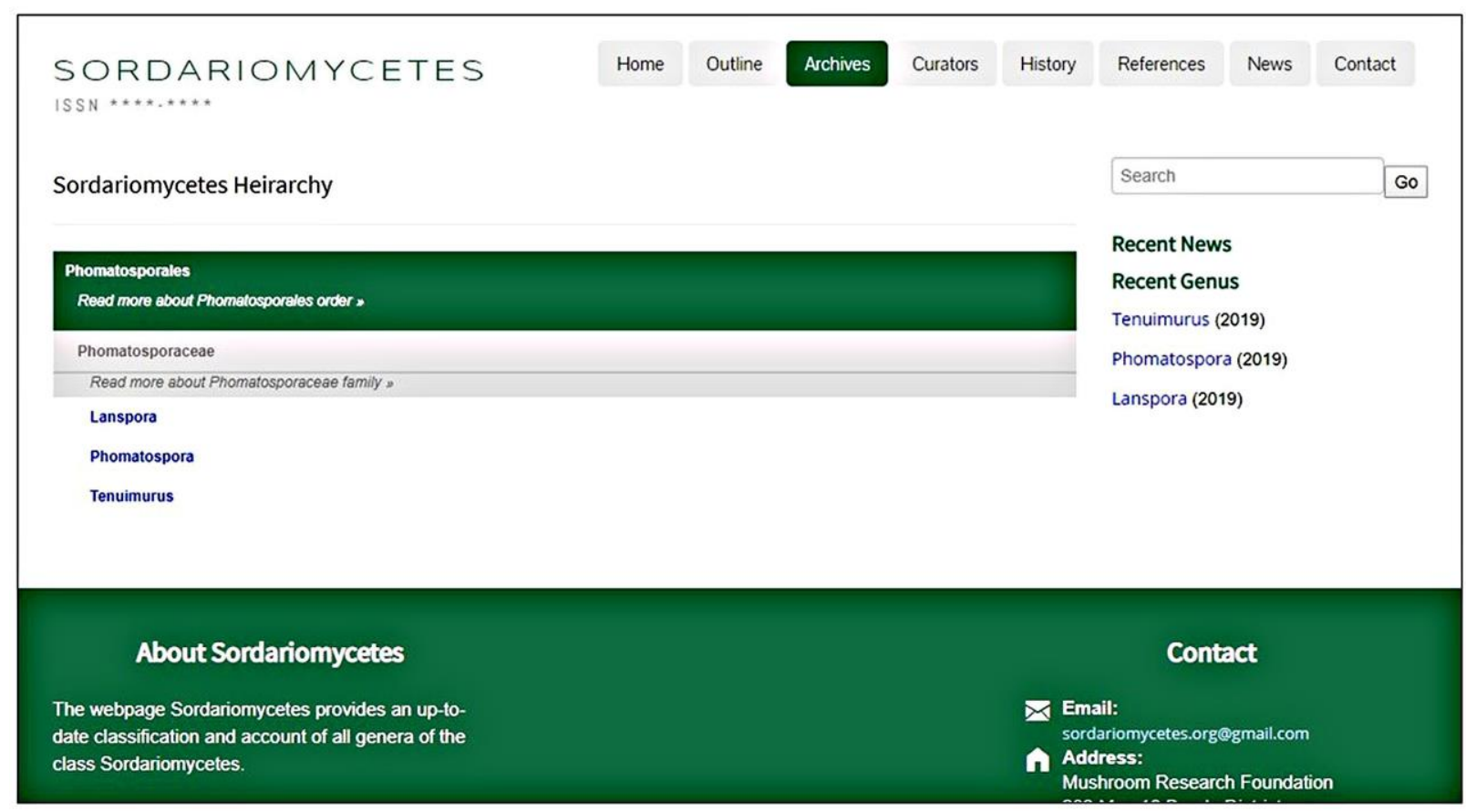

Fig. 5 - The 'Archives' section revealing Sordariomycetes taxa in a hierarchical order.

\section{Acknowledgements}

This work was financed by the Mushroom Research Foundation (MRF), Thailand. The Thailand Research Fund is equally thanked for the grant entitled "Biodiversity, phylogeny and role of fungal endophytes on above parts of Rhizophora apiculata and Nypa fruticans" (grant no: RSA5980068).

\section{References}

Alexopoulos CJ, Mims CW, Blackwell M. 1996 - Introductory Mycology. New York: John Wiley \& Sons Inc. 
Beimforde C, Feldberg K, Nylinder S, Rikkinen J et al. 2014 - Estimating the phanerozoic history of the Ascomycota lineages: combining fossil and molecular data. Molecular Phylogenetics and Evolution 78, 386-398.

Cai L, Jeewon R, Hyde KD. 2006 - Phylogenetic investigations of Sordariaceae based on multiple gene sequences and morphology. Fungal Biology 110, 137-150.

Daranagama DA, Hyde KD, Sir EB, Thambugala KM et al. 2018 - Towards a natural classification and backbone tree for Graphostromataceae, Hypoxylaceae, Lopadostomataceae and Xylariaceae. Fungal Diversity 88, 1-65.

Dayarathne M, Maharachchikumbura S, Jones E, Goonasekara I et al. 2017 - Neophyllachora gen. nov. (Phyllachorales), three new species of Phyllachora from Poaceae and resurrection of Polystigmataceae (Xylariales). Mycosphere 8, 1598-1625.

Dayarathne MC, Maharachchikumbura SSN, Jones EB, Wei D et al. 2019 - Phylogenetic revision of Savoryellaceae and evidence for its ranking as a subclass. Frontiers in Microbiology 10, 840.

Debbab A, Aly AH, Proksch P. 2013 - Mangrove derived fungal endophytes - a chemical and biological perception. Fungal Diversity 61, 1-27.

Doilom M, Hyde KD, Phookamsak R, Dai DQ et al. 2018 - Mycosphere Notes 225-274: types and other specimens of some genera of Ascomycota. Mycosphere 9, 647-754.

Eriksson OE, Winka K. 1997 - Supraordinal taxa of Ascomycota. Myconet 1, 1-16.

Hongsanan S, Sánchez-Ramírez S, Crous PW, Ariyawansa HA et al. 2016 - The evolution of fungal epiphytes. Mycosphere 7, 1690-1712.

Hongsanan S, Maharachchikumbura SSN, Hyde KD, Samarakoon MC et al. 2017 - An updated phylogeny of Sordariomycetes based on phylogenetic and molecular clock evidence. Fungal Diversity 84, 25-41.

Huang SK, Maharachchikumbura SSN, Jeewon R, Bhat JD et al. 2018a - "Lecanicillium subprimulinum (Cordycipitaceae, Hypocreales), a novel species from Baoshan, Yunnan". Phytotaxa 348, 99-108.

Huang SK, Jeewon R, Hyde KD, Bhat JD, Wen TC. 2018b - Novel taxa within Nectriaceae: Cosmosporella gen. nov. and Aquanectria sp. nov. from freshwater habitats in China. Cryptogamie Mycologie 39, 169-192.

Hyde KD, Jones EBG, Liu JK, Ariyawansa HA et al. 2013 - Families of Dothideomycetes. Fungal Diversity 63, 1-313.

Hyde KD, Nilsson RH, Alias SA, Ariyawansa HA et al. 2014 - One stop shop: backbones trees for important phytopathogenic genera: I. Fungal Diversity 67, 21-125.

Hyde KD, Maharachchikumbura SSN, Hongsanan S, Samarakoon MC et al. 2017 - The ranking of fungi: a tribute to David L. Hawksworth on his 70th birthday. Fungal Diversity 84, 1-23.

Hyde KD, Xu J, Rapior S, Jeewon R et al. 2019 - The amazing potential of fungi: 50 ways we can exploit fungi industrially. Fungal Diversity 31, 1-36.

Hyde KD, Norphanphoun C, Maharachchikumbura SSN, Bhat DJ et al. 2020 - Refined families of Sordariomycetes. Mycosphere 11, 305-1059.

Jaklitsch WM, Voglmayr H. 2012 - Phylogenetic relationships of five genera of Xylariales and Rosasphaeria gen. nov. (Hypocreales). Fungal Diversity 52, 75-98.

Jayasiri SC, Hyde KD, Ariyawansa HA, Bhat DJ et al. 2015 - The Faces of Fungi database: fungal names linked with morphology, phylogeny and human impacts. Fungal Diversity 74, 3-18.

Jayasiri SC, Hyde KD, Jones EBG, McKenzie EHC et al. 2019 - Diversity, morphology and molecular phylogeny of Dothideomycetes on decaying wild seed pods and fruits. Mycosphere 10, 1-186.

Jayawardena RS, McKenzie EHC, Chen YJ, Phillips AJL et al. 2019 https://onestopshopfungi.org/, a webpage to enhance identification of phytopathogenic genera. Asian Journal of Mycology 2, 281-286. 
Jeewon R, Wanasinghe DN, Rampadaruth S, Puchooa D et al. 2017 - Nomenclatural and identification pitfalls of endophytic mycota based on DNA sequence analyses of ribosomal and protein genes phylogenetic markers: A taxonomic dead end? Mycosphere 8, 1802-1817.

Jeewon R, Yeung QSY, Wanasinghe DN, Rampadarath S et al. 2018 - Hidden mycota of pine needles: Molecular signatures from PCR-DGGE and Ribosomal DNA phylogenetic characterization of novel phylotypes. Scientific Reports 8, 18053.

Jones EG, Pang KL, Abdel-Wahab MA, Scholz B et al. 2019 - An online resource for marine fungi. Fungal Diversity 96, 347-433.

Kaewchai S, Soytong K, Hyde KD. 2009 - Mycofungicides and fungal biofertilizers. Fungal Diversity 38, 25-50.

Kirk PM, Cannon PF, Minter DW, Stalpers JA. 2008 - Dictionary of the fungi, 10th edn. CABI, Wallingford.

Konta S, Hongsanan S, Tibpromma S, Thongbai B et al. 2016 - An advance in the endophyte story: Oxydothidaceae fam. nov. with six new species of Oxydothis. Mycosphere 7, 1425-1446.

Li JF, Phookamsak R, Jeewon R, Tibpromma S et al. 2017 - Establishment of Zygosporiaceae fam. nov. (Xylariales, Sordariomycetes) based on rDNA sequence data to accommodate Zygosporium. Mycosphere 8, 1855-1868.

Lin CG, McKenzie EH, Liu JK, Jones EB, Hyde KD. 2019 - Hyaline-spored chaetosphaeriaceous hyphomycetes from Thailand and China, with a review of the family Chaetosphaeriaceae. Mycosphere 10, 655-700.

Luo Z, Hyde KD, Liu J, Maharachchikumbura SSN et al. 2019 - Freshwater Sordariomycetes. Fungal Diversity 99, 451-660.

Maharachchikumbura SSN, Hyde KD, Jones EBG, McKenzie EHC et al. 2015 - Towards a natural classification and backbone tree for Sordariomycetes. Fungal diversity 72, 199-301.

Maharachchikumbura SSN, Hyde KD, Jones EBG, McKenzie EHC et al. 2016 - Families of Sordariomycetes. Fungal Diversity 79, 1-317.

Monkai J, McKenzie EHC, Phillips AJL, Hongsanan S et al. 2019 - https://fungalgenera.org/: A web-based utility of classification and notes for all genera of fungi. Asian Journal of Mycology 2, 298-305.

Pem D, Hongsanan S, Doilom M, Tibpromma S et al. 2019 - https://www.dothideomycetes.org: An online taxonomic resource for the classification, identification, and nomenclature of Dothideomycetes. Asian Journal of Mycology 2, 287-296.

Pérez-Ortega S, Garrido-Benavent I, Grube M, Olmo R, de los Ríos A. 2016 - Hidden diversity of marine borderline lichens and a new order of fungi: Collemopsidiales (Dothideomyceta). Fungal Diversity 80, 285-300.

Pinnoi A, Phongpaichit P, Jeewon R, Tang AMC et al. 2010 - Phylogenetic relationships of Astrocystis eleiodoxae sp. nov. (Xylariaceae). Mycosphere 1, 1-9.

Rashmi M, Kushveer JS, Sarma VV. 2019 - A worldwide list of endophytic fungi with notes on ecology and diversity. Mycosphere 10, 798-1079.

Réblová M, Štěpánek V. 2018 - Introducing the Rhamphoriaceae, fam. nov. (Sordariomycetes), two new genera, and new life histories for taxa with Phaeoisaria- and Idriella-like anamorphs. Mycologia 110, 750-770.

Samarakoon MC, Hyde KD, Promputtha I, Hongsanan S et al. 2016 - Evolution of Xylariomycetidae (Ascomycota: Sordariomycetes). Mycosphere 7, 1746-1761.

Semenova EF, Shpichka AI, Moiseeva IY. 2012 - About essential oils biotechnology on the base of microbial synthesis. Pharmaceutical Sciences 4, 29-31.

Senanayake IC, Maharachchikumbura SSN, Hyde KD, Bhat JD et al. 2015 - Towards unraveling relationships in Xylariomycetidae (Sordariomycetes). Fungal Diversity 73, 73-144.

Senanayake IC, Maharachchikumbura SSN, Jeewon R, Promputtha I et al. 2017 Morphophylogenetic study of Sydowiellaceae reveals several new genera. Mycosphere 8, $172-217$. 
Senanayake IC, Jeewon R, Chomnunti P, Wanasinghe DN et al. 2018 - Taxonomic circumscription of Diaporthales based on multigene phylogeny and morphology. Fungal Diversity 93, 241443.

Senwanna C, Phookamsak R, Doilom M, Hyde KD, Cheewangkoon R. 2017 - Novel taxa of Diatrypaceae from Para rubber (Hevea brasiliensis) in northern Thailand; introducing a novel genus Allocryptovalsa. Mycosphere 8, 1835-1855.

Shang QJ, Hyde KD, Jeewon R, Khan S et al. 2018 - Morpho-molecular characterization of Peroneutypa (Diatrypaceae, Xylariales) with two novel species from Thailand. Phytotaxa $356,1-18$.

Wang H, Guo S, Huang M, Thorsten LH, Wei J. 2010 - Ascomycota has a faster evolutionary rate and higher species diversity than Basidiomycota. Science China Life Sciences 53, 1163 1169.

Wang XW, Bai FY, Bensch K, Meijer M et al. 2019 - Phylogenetic re-evaluation of Thielavia with the introduction of a new family Podosporaceae. Studies in Mycology 93, 155-252.

Xu J, Yang X, Lin Q. 2014 - Chemistry and biology of Pestalotiopsis derived natural products. Fungal Diversity 66, 37-68.

Yang J, Liu NG, Liu JK, Hyde KD et al. 2018 - Phylogenetic placement of Cryptophiale, Cryptophialoidea, Nawawia, Neonawawia gen. nov. and Phialosporostilbe. Mycosphere 9, 1132-1150.

Zhang N, Castlebury LA, Miller AN, Huhndorf SM et al. 2006 - An overview of the systematics of the Sordariomycetes based on four-gene phylogeny. Mycologia 98, 1077-1088.

Zhao RL, Zhou JL, Chen J, Margaritescu S et al. 2016 - Towards standardizing taxonomic ranks using divergence times - a case study for reconstruction of the Agaricus taxonomic system. Fungal Diversity 78, 239-292. 